\title{
Assuring Corporate Social Responsibility Reports: Motives and Challenges of Egyptian Companies
}

\author{
Mona Ganna \\ B.Com. (Hons), MSc, Ph.D., GTA \\ mona.gana@commerce.tanta.edu.eg
}

\author{
Laila Aladwey \\ B.Com. (Hons), MSc, Ph.D., FHEA \\ laila.eladawi@commerce.tanta.edu.eg
}

\author{
Accounting Department \\ Faculty of Commerce \\ Tanta University \\ Tanta, Gharbia, Egypt
}

\begin{abstract}
This study aims at examining the contemporary practice of Corporate Social Responsibility (CSR) assurance and exploring its future in Egypt. Forty-four managers working in Egyptian listed companies with a recognized CSR experience are surveyed to attain their perceptions on the issues examined. Kruskal Wallis test are utilized for hypotheses testing. Results reveal that the lack of awareness about the assurance importance and its high cost are perceived as the main hindrances of assurance reports in Egypt. Respondents' level of experience has no impact on their perceptions of the Egyptian companies' motives of to assure CSR reports. However, the respondents' experience level influences their realization of certain challenges, such as the dearth of stakeholders' pressure; the concerns about auditors' independence and the lack of the awareness of importance of CSR assurance, that may limit Egyptian companies to undertake the assurance decision. Furthermore, respondents' experience level affect on their perceptions of the urgency of unified reporting guidelines as well as the stakeholders' pressure to enhance the future of CSR assurance in Egypt. In addition, the companies' size influences the respondents' perceptions about the identified factors that stimulates Egyptian companies to assure CSR reports, excluding the need to enhance the external reporting. Also, the companies' size affects the respondents' view of stakeholders' pressure as a factor that imped Egyptian companies from undertaking the assurance decision. Finally, for each identified strand enhance the diffusion of CSR assurance in Egypt, our results report a significant impact of the companies' size on the respondents' perceptions.
\end{abstract}

JEL Classifications: C13, M41, 016.

Keywords: CSR Assurance, Egypt, EGX100 index.

\section{Introduction}

Globally, there is a great concern about the impact of the economic development on the sustainability of social and environmental resources. This concern is increasing these days with the huge impact we are experiencing of the global warming on the sustainability of the planet and its resources. These concerns were interpreted as requirements from corporations to disclose about their activities and their effects on economy, environment, and society in what is called Corporate Social Responsibility (CSR) reports or sustainability reports or triple bottom line report. Global Reporting Initiative (GRI) defined CSR Reporting or Sustainability Reporting

* This article was submitted in October 2021, and accepted for publishing in November 2021.

(c) Arab Administrative Development Organization - League of Arab States, 2025, pp. 227-240. DOI: 10.21608/aja.2021.101935.1172 
as "an organization's practice of reporting publicly on its economic, environmental, and/or social impacts, and hence its contributions- positive or negative- toward the goal of sustainable development" (Global Reporting Initiative, 2016: 3). The objective of reporting is to help corporations understand, measure, and communicate the effect of their operations on the context in which they are operating i.e., economy, environment, and society (Fernandez-Feijoo et al., 2019). These reports emphasize on the responsibility of organizations not only toward their shareholders, in terms of maximizing their profits, but also toward the whole society and coming generations in terms of maintaining their ability to meet their own needs from the environment and society (Ackers, 2008; Global Reporting Initiative, 2016).

It is noted that there is an increase in the number of companies reporting about their economic, environmental, and social impact (Jones et al., 2015). According to Ernst and Young (2010), CSR reporting is practiced by various types of organizations and is not limited to a specific industry or region or size of organizations. Despite the CSR reports are voluntary, companies report about their sustainability practices as a response to the increasing pressure from investors, nongovernmental organizations (NGOs), community associations, customers, suppliers, and employees who ask for more information about the organizations' impact on society (Ernst and Young, 2010; Ackers, 2017).

With the increase in reporting about the social responsibility of organizations, the concerns about the reliability and credibility of such information increased as well (Ruiz-Barbadillo and Martinez-Ferrero, 2020). Accordingly, many companies tend to assure their CSR reports. Assurance is defined as "an engagement in which a practitioner aims to obtain sufficient appropriate evidence in order to express a conclusion designed to enhance the degree of confidence of the intended users other than the responsible party about the subject matter information" (IFAC, 2013: 7). Drawing from IAASB definition to assurance, the main objective of CSR assurance is to enhance the stakeholders' trust in the information reported about the organization's social responsibility activities (Fernandez-Feijoo et al., 2019; Ruiz-Barbadillo and Martinez-Ferreor, 2020).

The issuance of standards guiding the assurance process of CSR reports has supported the movement toward increasing the number of companies engaging in third-party assurance of their reports (Carrington, 2019). In 2004, the International Auditing and Assurance Standards Board (IAASB) issued the ISAE 3000 that is concerned with assurance engagements other than audits or reviews of historical financial information. The standard was revised in 2013. In 2013, GRI issued the external assurance of sustainability reporting standards. Also, AccountAbility organization that is "a global consulting and sustainability standard firm" (AA1000AS v3, 2020: 1) issued AA1000AS in 2008, extended by ADDENDUM by 2018 and released version 3 in 2020. The existence of standards that guide the assurance process facilitate the role of assurance providers and give a comparability advantage to the assurance statement. Also, it prevents one of the main challenges that may face companies in their journey of getting their CSR reports assured. Among various reasons, not having a generally accepted standards for assuring CSR reports have been recorded as an obstacle for making the decision to assure CSR reports.

Despite the growing number of studies investigating the factors that affect the companies' decision to assure their CSR reports UK and worldwide (e.g., Jones et al., 2015; Al-Shaer and Zaman, 2019; Channuntapipat et al., 2019; Mnif Sellami et al., 2019), there is still a scarcity in the research conducted in developing countries such as Egypt (Diab and Abdelazim, 2018). Diab and Abelazim (2018) explored the current state of assurance of integrated reporting in Egypt from the auditors' perspective. This study focuses on the perception of the service receiver rather than providers. So, the objective of this study is to examine the perception of participants from the Egyptian companies regarding the motives for companies to adopt CSRA and the challenges that face the spread of assuring CSR reports.

Based on findings from previous research (Park and Borson, 2005; Sawani et al., 2010), a questionnaire was designed to collect data from 44 respondents who work in Egyptian companies that are listed in the Egyptian Stock Exchange (EGX) for at least five years and with experience in CSR activities. The questionnaire is 
designed mainly to collect information about how the CSR assurance activities are perceived among various Egyptian companies. Questions about the motives of companies to ensure their CSR reports and the challenges that prevent companies to take this action despite the recorded benefits of CSR assurance.

Overall, this study positively contributes to the understanding of the assurance practice for CSR reports. The findings of the study can assist the regulatory bodies through directing their attention to the gap between the reported importance of assuring CSR reports and the lack of awareness of this importance among the companies. The study might motivate these regulatory bodies and policy makers to take actions toward informing the Egyptian companies with the benefits of assuring CSR reports. Also, the study might motivate companies to pursuing CSR assurance. An action that might lead to decreasing the fees of the service provided from auditing companies.

The rest of the paper is organized as follows: the following part provides an overview of CSR reporting globally and in Egypt. It also discusses the main findings of the previous literature about the motives and challenges of assuring CSR repots. The subsequent section is research design and data collection methods. This section is followed by findings section. Discussion and conclusion are the last section in this paper.

\section{Literature Review}

Recent years has witnessed a global increase in the voluntary disclosure of non-financial information in the form of Corporate Social Responsibility Reports (Kolk and Perego, 2010). Previous studies have detected Spain to be on the top of the countries reporting on their social responsibility (Sierra et al., 2013). This increase in CSR reporting was not limited to European countries. Ackers (2009) and Ackers and Eccles (2015) have reported the increase in CSR report in South Africa too. Studies proved that this growth in CSR reporting came in response to companies' stakeholders who are interested in environmental and social performance of companies (Gillet, 2012). Information presented in these reports give indications to investors about the companies' corporate risk and the future financial performance of organizations (Kolk and Perego, 2010).

Despite the role played by the CSR reports in improving the organizations' financial performance and consequently the trust of investors in the organization, the confidence of investors can be increased through assuring these reports (Branco et al., 2014). Generally, assurance is a service that "aims to provide credibility to the information published in corporate report" (Carrington, 2019: 157). As one of the growing types of reports issued by corporations in most of the countries, Corporate Social Responsibility reports are gaining attention by various stakeholders of corporation. So, there has been a call to assure the information included in these reports to give their users more confidence in making decisions based on the information provided.

Since its launch in 2002, GRI guidelines recommended providing third-party assurance for the sustainability reports (GRI-Assurance, 2013). Various publications have detected and investigated the benefits of getting CSR reports assured (Park and Brorson, 2009; Simnett et al., 2009; Branco et al., 2014; Al-Shaer and Zaman, 2019). In UK, Al-Shaer and Zaman (2019) found that improving the performance of corporations, enhancing the reputation, and enhancing the reliability and credibility of CSR reports are the main benefits of assuring CSR reports. These benefits are not limited to UK, but they are extended to other countries such as Sweden (Park and Brorson, 2009), Portugal (Branco et al., 2014), and internationally (Simnett et al., 2009).

An important question that remains as the foundation of many studies is what motivates companies to assure their CSR reports and what inhibits other companies from assuring their reports. In that endeavour, Al-Shaer and Zaman (2019) examined UK FSTSE 350 to investigate the potential relationship between the inclusion of sustainability-related target in CEO compensation and the assurance of their sustainability reports. They found that assuring sustainability reports are highly dependent on the inclusion of sustainability terms in CEO compensation contracts (Al-Shaer and Zaman, 2019). 
Simnett et al., (2009) distinguished between three levels of motives for assuring the sustainability reports: company level, industry level, and country level factors. Company size was proved to have a positive relationship with the tendency of companies to assure their CSR reports despite the country in which the study was conducted. This finding was true in Portugal where Branco et al., (2014) have conducted Bivariate and Multivariate non-parametric statistics to explore the factors that affect the decision of companies to assure their CSR reports. Among the various factors they examined, the company size with other financial factors were proved to be determinants of CSR assurance practice. Firm size was also found to be positively and significantly influencing companies' decision to assure their CSR reports in Finland (Dutta, 2020). In South Africa, Ackers and Eccles (2015) found that large companies are more likely to provide assurance to their CSR reports. At the global level, the same finding was proved to be right in Simnett et al., (2009) study using a sample from 31 countries. In contrast to these findings, Kolk and Perego (2010) in their study for Fortune Global 250 companies and Cho et al., (2014) study for USA Fortune 500 companies, both studies found that firm size "is not significantly associated with [CSR] assurance choice" (Choe et al., 2014: 138).

In terms of the industry-related factors, Simnett et al., 2009 found that companies working in industries such as mining, utilities, and finance get their CSR reports assured. Companies in these sectors have a higher need to enhance the credibility of information provided for the stakeholders, so they get their CSR reports assured. On the other hand, companies in the manufacturing sector were less likely to get their reports assured (Simnett el al., 2009). Branco et al., (2014) also found that industry sector influences the decision of assuring CSR reports in Portugal. They proved that companies from utilities, financials and technology and telecommunications are more likely to engage in third-party assurance activities for their CSR reports. Other sectors such as oil and basic materials are also engaging in assurance but with lesser probabilities (Branco et al., 2014). Contrary to these studies, Sierra et al., (2013) in their study for Ibex-35 companies in Spain found that there is no association between the industry sector and the decision to assure CSR reports.

At the country level, previous studies have categorized the effect of countries to countries with legal system based on code law vs. common law, countries with weak enforcement mechanisms, countries with higher pressure for CSR (Kolk and Perego, 2010), countries that are more shareholder-orientated vs stakeholder- orientated (Simnett et al., 2009), and countries with low investor protection mechanisms (Herda et al., 2014). Kolk and Perego (2010) found that firms located in stakeholder-oriented countries are more likely to assure their CSR reports. Additionally, they found that the demand for assuring CSR reports is significantly associated with the legal environment in which a firm operates (Kolk and Perego, 2010). Companies domiciled in countries that have weaker investor protection are highly expected to decide to assure their CSR reports and decide to have higher quality assurance (Herda et al., 2014). Simnett et al., (2009) study focused on the effect of the country level factors on the choice of assurance provider, whether auditing or consulting firms. In that regard, they found that companies in stakeholder-oriented countries tend to choose a member of the auditing profession to assure their CSR reports.

While the above-mentioned studies provided an explanatory power to the external factors that influence the decision of assuring CSR reports, another stream of research investigated the internal motives of assuring CSR reports in respect to the expected benefits of CSR assurance. Simnett et al., (2009) identified the credibility enhancement as a major motive for assuring CSR reports. Studies that used questionnaire and interviews as their data collection methods were able to understand the perception and motives of companies' managers to take the decision to assure or not assure CSR reports (e.g., Park and Borson, 2005; Sawani et al., 2010) or content analysis (e.g., Jones et al., 2014). However, this stream of research is scarce.

In a study of 28 Swedish companies, Park and Borson, (2005) found that managers' perception about the benefits of assuring CSR reports were positive. Interviewees admitted that third-party assurance helped organizations in developing efficient internal reporting systems and increasing the credibility of published 
data (Park and Borson, 2005). Motives behind assuring CSR reports were not different in Malysia where Sawani et al., (2010) conducted their exploratory study to examine the motivating factors for CSR reporting. Interviews revealed various themes of these motivating factors: enhancing transparency that improves the communication with stakeholders, CSRA support the data management process in organizations, and attract customers (Sawani et al., 2010). Other factors that motivate companies to assure their CSR reports are to become a current trend, create examples to others, and win award (Park and Borson, 2005; Sawani et al., 2010).

On the other side, these studies also examined the barriers that prevent companies from assuring their CSR reports. Among these barriers are the high cost of assuring activities (Park and Borson, 2005; Sawani et al., 2010). Some interviewees admitted that there is no wide consensus "that third party assurance would result in enhanced credibility" (Park and Borson, 2005: 1104).

The previous presentation of literature review revealed a scarcity of research that depend on the perception and opinions of managers involved in the preparation of CSR reports and the decision of assuring or not assuring them. Such scarcity of research increases the call of conducting more of this type of research. Also, there is a scarcity in the research provided in developing countries. Consequently, this paper contributes to CSR assurance literature through exploring the assurance practices for non-financial reports in the Egyptian context and understanding the managers perceptions about what factors support or hinder their decision to assure CSR reports.

\section{The Current State of CSR Assurance in Egypt}

According to study made by United Nations Development Programme (UNDP) and Industrial Modernization Centre (IMC) in Egypt in 2016, the promotion of CSR in Egypt starting in 2004 when the UNDP launched the Global Compact Local Network in Egypt (Sherif, 2016). Partners in this network were committed to promoting CSR and United Nations Global Compact (UNGC) principles. The Egyptian Stock Exchange (EGX) has supported the promotion of CSR reporting in Egypt. In 2009, EGX joined the United Nations' Sustainable Stock Exchange initiative (Diab and Abd-Elazim, 2018).

In 2010, EGX initiated the 'Environment Social and Governance Index' in collaboration with the Egyptian Institute of Directors, Standard and Poor's and Crisil institution. This index contains the companies that satisfy the requirements of corporate governance as well as the social responsibility (Ghareb, 2015). The best 30 companies in the index represent most of the sectors in the market: Banks, food, telecommunication, clothes, construction, chemicals, medicine and hospitals and others. None of these sectors are more represented in the index than the other (According to index on June 30,2020). While there is a slow growth of the adoption of CSR activities in Egypt (Darrag and Cowther, 2017), there is a slower adoption of CSR assurance among the Egyptian companies. Diab and Abdelazim (2018) study has detected the assurance practices for CSR reports are still in its infancy stages contrary to the situation in a country such as South Africa. So, the objective of our study is to investigate the reasons behind this limited adaptation of assurance practices for CSR reports.

\section{Hypotheses Development}

Due to the scarce evidence from the Egyptian context about the factors that may affect the companies' decision whether to assure their CSR reports or not, this study is drawing its objectives through the extension of the findings of previous research. The main objective of our study is to examine the current state of CSR assurance in Egypt and to explore the driving forces that stimulate the diffusion of the assurance practise in the future. This objective could be satisfied by achieving the following three sub-objectives:

- Identifies the perceptions toward the factors that may motivate Egyptian companies to assure CSR reports. 
- Examines the perceptions about the challenges that prevent Egyptian companies from assuring CSR reports.

- Explore the perceptions about the driving forces that encourage the diffusion of CSR assurance in Egypt.

As noted above, previous studies found that the company size is positively related to the tendency of companies to assure their CSR reports (e.g., Dutta, 2020; Ackers and Eccles, 2015). It is more common that companies with larger size are more likely to engage in activities that have an influence on the society and the environment (Ackers, 2017). Previous research that studied the different factors influencing the decision of companies to assure their CSR reports. Among these factors is the company size (e.g., Branco et al., 2014; Choe et al., 2014). Despite the different contexts in which these studies were conducted, a positive relationship between the firm sizes the tendency to assure their CSR reports were found. Accordingly, it can be argued that in large companies, the discourse of assuring CSR reports can be extensive. Whether the company assure its CSR reports or not, managers and employees in such organizations will be aware of the reasons why their companies tend to assure and the challenges that may prevent them or prevent other companies from assuring their CSR reports.

Another aspect that might influence the perception of the participants about the positive and negative forces that influence companies' decision to assure or not assure their CSR report is their level of experience. The level of experience of employees and their knowledge of the issues that may face their companies can be measured by the number of years they are spending in the company (Hafsi and Turgut, 2013). Previous research was concerned about studying the relationship between the years of experience of people working in the business field and their perception about the motives and issues of adopting a specific financial service. For example, the auditors' years of experience affected their perception about the issues that may affect the financial reporting quality (Amin and Mohamed, 2016). In this study we are examining the relationship of both the company size and years of experience of participants on their perception about the factors that influence the company's decision about assuring CSR reports and their vision for the future of the practice in Egypt. Accordingly, the research hypotheses are $\mathrm{H} 1, \mathrm{H} 2, \mathrm{H} 3$ and $\mathrm{H} 4$ are related to first and second sub-objectives, while $\mathrm{H} 5$ and $\mathrm{H} 6$ are related to the third objective.

- H1. Respondents' level of experience has no effect on their perceptions about the factors that may motivate Egyptian companies toward CSR assurance.

- H2. Companies' size has no effect on the respondents' perceptions about the factors that may motivate Egyptian companies toward CSR assurance.

- H3. Respondents' level of experience has no effect on their perceptions about the challenges that prevent Egyptian companies from assuring CSR reports.

- H4. Companies' size has no effect on the respondents' perceptions about the challenges that prevent Egyptian companies from assuring CSR reports.

- H5. Respondents' level of experience has no effect on their perceptions about the driving forces that encourage the diffusion of CSR assurance.

- H6. Companies' size has no effect on the respondents' perceptions about the driving forces that encourage the diffusion of CSR assurance.

\section{Research Design}

\section{Sample}

Our sample covers the Egyptian companies listed in the Egyptian Stock Exchange (EGX) that have an experience in disclosing about CSR activities. The selected companies need to satisfy three main criteria as follows. First, the company need to be listed in EGX for at least the last five years. Second, it has at least one year experience in CSR reporting. Such experience was determined through company reporting for their CSR 
activities either in a stand-alone report, in their annual report, or on their website pages. Finally, the company is with or without CSR assurance report. According to these criteria, only fifty-seven Egyptian companies are eligible for our study. We circulate our questionnaire to the participating managers working in such companies via their Emails shown in the official sites of their com-
Table I. Sample Selection Process

\begin{tabular}{ll}
\hline The total number of companies listed in EGX & 214 \\
\hline $\begin{array}{ll}\text { Less, companies listed in EGX in 2016 } \\
\text { (beyond the five years threshold) }\end{array}$ & (20) \\
\hline Less, companies that do not disclose CSR activities & $(137)$ \\
\hline No of eligible companies for our sample & 57 \\
\hline No of respondents & 44 \\
\hline
\end{tabular}
panies, their Linkedln accounts, short phone calls or Zoom meetings. Eventually, our sample ends up with forty-four respondents at the different managerial levels. Table I. shows the sample selection process.

\section{Questionnaire Design and Reliability Test}

Our questionnaire is divided into three main sections. First, we collect data about the demographic characteristics of the respondents, mainly their gender; years of experience; job title as well as their companies' size. Our aim in the second section is to understand the respondents' perceptions about the factors that may motivate them to get their CSR reports assured and challenges that may hinder the adoption of CSR Assurance. Finally, our third part is intended to address the future of CSR Assurance in Egypt. To rank the respondents' perceptions in the second and third sections, we utilize the five-point Likert scale. The scale is decoded as follow: one as "strongly disagree"; two as "disagree"; three for "neutral"; four for "agree" and five as "strongly agree".

The reliability scale of Cronbach's alpha coefficient is calculated to assess the internal consistency for our questionnaire. Based on Sekaran (2000), the acceptable level of the internal consistency among questionnaire' items need to be greater 0.7. Accordingly, as shown in Table II, since the Cronbach's alpha coefficient is 0.899 , our questionnaire demonstrates justifiable reliability scale.

Table II. Reliability Statistics (Cronbach's Coefficient Alpha)

\begin{tabular}{ccc}
\hline & Cronbach's Alpha & N of Items \\
\hline Overall Reliability & 0.899 & 18 \\
\hline
\end{tabular}

\section{Method}

We utilize the descriptive frequencies statistics and Kruskal Wallis test to identify the effect of level of experience on the respondents' perceptions about the factors that induce Egyptian companies toward CSR assurance; the challenges that may hinder the diffusion of the assurance service and the future of such service in Egypt. In addition, we conduct some additional analysis, via content analysis, to get more insights about the nature of companies that produce the stand-alone CSR reports.

\section{Results and Discussion}

\section{Descriptive Analysis}

Table III provides the descriptive information about the demographic characteristics of the questionnaire' respondents and their companies. As shown in Panel A, Table III, the forty-four respondents were classified as 36 males (81.8 percent) and only 8 females representing 18.2 percent of the sample. According to the job title, the respondents comprise of 6 managers (13.6 percent), 2 consultants ( 4.5 percent), 22 senior employees (50 percent), and 14 junior employees (31.8 percent). A total of 18 (40.9 percent) respondents have less than 10 years of experience, 20 (45.5 percent) respondents have experience between 10 years and 20 years, and 6 (13.6 percent) have more than 20 years of experience.

The tenure of the examined companies within the EGX is around 15.4 years where the minimum number of years is 5 years, and the maximum is 39 years. Panel B, Table III reveals the attributes of the respondents 'companies. 
The industrial sectors of the examined companies can be classified as follows. Around 27.3 percent respondents were working in service organizations including healthcare and medicine, entertainment and tourism, and transportation and shipping. In addition, 9.1 percent of respondents are working from manufacturing companies including food, drinks and cigarettes, and building resources companies. With an equal figure, (9.1 percent) is also working in communication, media and information technology. 22 (50 percent) respondents from financial, both banking and non-banking, institutions. The lowest percentage (4.5 percent) of respondents are working in constructions companies. The companies in which respondents are working varies in their size. 12 companies ( 27.3 percent) are small companies with less than 50 employees. 8 (18.2 percent) companies are from 50 to 199 employees. 4 (9.1 percent) companies have 200 to 1000 employees, while 16 (36.4 percent) companies have employees ranging from 1000 to 5000, and finally 4 (9.1 percent) companies have more than 5000 employees.

Table IV shows the descriptive frequencies of respondents' responses about the questions designed for testing the hypothesis. The results reveal that the score of the viewpoints of the sample respondents regarding the incentives toward CSR assurance are ranging from 1.95 to 2.86 . The results reveal that the main motives for companies to ensure their CSR reports are improving the company image in front of the various stakeholders including investors and potential employees. In terms of the chal-
Table III. The Respondents' Descriptive Frequencies

\begin{tabular}{|c|c|c|c|}
\hline & & Frequency & Percentages \\
\hline \multicolumn{4}{|c|}{ Panel A, The respondents' Personal Attributes } \\
\hline \multirow{2}{*}{ Gender } & Male & 36 & 81.8 \\
\hline & Female & 8 & 18.2 \\
\hline \multirow{4}{*}{ Job Rank } & Managers & 6 & 13.6 \\
\hline & Consultant & 2 & 4.5 \\
\hline & Senior employee & 22 & 50.0 \\
\hline & Junior employee & 14 & 31.8 \\
\hline \multirow{3}{*}{$\begin{array}{l}\text { Years of Expe- } \\
\text { rience }\end{array}$} & Less than 10 years & 18 & 40.9 \\
\hline & 10-20 years & 20 & 45.5 \\
\hline & More than 20 years & 6 & 13.6 \\
\hline \multicolumn{4}{|c|}{ Panel B, The Attributes of Respondents' Companies } \\
\hline \multirow{5}{*}{$\begin{array}{l}\text { Companies' } \\
\text { industry sector }\end{array}$} & Service & 12 & 27.3 \\
\hline & Manufacturing & 4 & 9.1 \\
\hline & Information Technology & 4 & 9.1 \\
\hline & Financial (banking and non-banking) & 22 & 50.0 \\
\hline & Constructions & 2 & 4.5 \\
\hline \multirow{5}{*}{$\begin{array}{l}\text { Companies' } \\
\text { Size (Number } \\
\text { of Employees) }\end{array}$} & Less than 50 & 12 & 27.3 \\
\hline & From 50 to 199 & 8 & 18.2 \\
\hline & From 200 to 1000 & 4 & 9.1 \\
\hline & From 1000 to 5000 & 16 & 36.4 \\
\hline & More than 5000 & 4 & 9.1 \\
\hline
\end{tabular}

Table IV. Descriptive Frequencies for Respondents' Responses Items N Min Max Mean SD

Panel A: Incentives toward CSR assurance.

\begin{tabular}{llllll}
\hline Improves its image for investors & 44 & 1 & 5 & 2.86 & 1.760 \\
\hline Improves employee's recruitment process & 44 & 1 & 5 & 2.86 & 1.760 \\
\hline Improves customer appeal & 44 & 1 & 5 & 1.95 & 1.413 \\
\hline Improves the company image among its stakeholders & 44 & 1 & 5 & 2.86 & 1.760 \\
\hline Enhance credibility of CSR report & 44 & 1 & 5 & 2.68 & 1.736 \\
\hline Improves internal reporting process & 44 & 1 & 5 & 1.95 & 1.413 \\
\hline Improves external reporting & 44 & 1 & 5 & 2.50 & 1.691 \\
\hline Improves internal control process & 44 & 1 & 5 & 1.95 & 1.413 \\
\hline
\end{tabular}

Improves internal control process

Panel B: Challenges hinders the adoption of CSR assurance

\begin{tabular}{llllll}
\hline Assurance fees are too high & 44 & 1 & 5 & 2.68 & 1.962
\end{tabular}

\begin{tabular}{llllll}
\hline There is no pressure from stakeholders & 44 & 1 & 5 & 2.32 & 1.865
\end{tabular}

\begin{tabular}{lllllll}
\hline Third party assurance does not add any value to & & & & & & \\
44 & & 2.14 & 1.786
\end{tabular} the report

\begin{tabular}{llllll}
\hline Credibility can be increased through other factors & 44 & 1 & 5 & 2.32 & 1.865
\end{tabular}

\begin{tabular}{llllll}
\hline Lack of independence of CSR assurance providers & 44 & 1 & 5 & 1.77 & 1.553
\end{tabular}

\begin{tabular}{lllllll}
\hline There is no awareness about the importance of the & & & & & & \\
44 & & 2.86 & 1.984
\end{tabular} assurance

Panel C: Strands encourage the diffusion of CSR assurance

\begin{tabular}{llllll}
\hline Providing generally accepted reporting guidelines & 44 & 1 & 5 & 2.14 & 1.786 \\
\hline
\end{tabular} \begin{tabular}{llllll}
\hline Increased pressure from stakeholders & 44 & 1 & 5 & 3.41 & 1.945
\end{tabular} Increased awareness about the importance of $44 \quad \begin{array}{lllll}5 & 3.23 & 1.975\end{array}$ third-party assurance for CSR repots

$\begin{array}{lllll}44 & 1 & 5 & 3.23 & 1.975\end{array}$

$\begin{array}{llllll}\text { Proactive approaches from leading companies in } & 44 & 1 & 5 & 2.14 & 1.786\end{array}$ the sector 
lenges that face companies and prevent them from assuring CSR reports, the score of the viewpoints of the sample respondents ranges from 1.77 to 2.86 . The most agreed upon reason behind the non-assurance of CSR reports is the lack of awareness of the necessity of assurance for enhancing the credibility of the information reported. Finally, the score of viewpoints of respondents regarding the factors that influence the future spread of CSR assurance service ranges from 2.14 to 3.41. The respondents believe that increasing the pressuring from the various stakeholders of the companies toward assuring CSR reports is the main factor that will lead to the diffusion of CSR assurance practices.

\section{Hypothesis Testing}

Table V shows the results of the Kruskal-Wallis test. Panel A, Table V reveals that the respondents' level of experience has no effect on their perceptions toward each incentive may stimulate Egyptian companies to assure CSR reports. At the different significant levels of $1 \% ; 5 \%$ and $1 \%$, we fail to reject $\mathrm{H}_{1}$ for each motive. Additionally, Panel A, Table $V$ indicate that the companies' size has significant effect on the respondents' views about each identified motive of Egyptian companies to undertake the assurance decision, except only for their desire to improves the external reporting, thus we partially fail to reject $\mathrm{H}_{2}$. Specifically, the respondents' perceptions may be different subject to their companies' size regarding their incentives to enhance the companies' image for investors ( $p$-value $<0.02$ at significance threshold of 0.05 ); refine the employment processes ( $p$-value $<0.01$ at significance threshold of 0.01); increase the customers' loyalty ( $p$-value $<0.09$ at significance threshold of 0.1 ); promote better view from stakeholders' perspective ( $p$-value $<0.01$ at significance threshold of 0.01 ); add value to CSR reports ( $p$-value $<0.02$ at significance threshold of 0.05); improve the internal reporting process ( $p$-value $<0.03$ at significance threshold of 0.05 ); and enhance the internal control mechanism ( $p$-value $<0.09$ at significance threshold of 0.10 ).

Panel B, Table V indicates the respondents' level of experience has significant impact on their perceptions about three identified challenges that may hinder Egyptian companies to assure CSR reports, according $\mathrm{H}_{3}$ is partially accepted. That is, the results indicate that the experience level matters regarding $g$ the perceptions toward the lack of stakeholders' pressure on Egyptian companies toward CSR assurance ( $p$-value $<0.03$ at significance threshold of 0.05); the fear toward invading the independence of the assurance providers ( $p$-value $<0.01$ at significance threshold of 0.01 ) and the dearth of the awareness of the urgency of the assurance in enhancing companies' values ( $p$-value $<0.10$ at significance level of 0.10 ). In addition, at all significance thresholds, Panel $B$, Table $V$ indicate that $\mathrm{H}_{4}$ is rejected for all identified hinderance to conduct CSR assurance except only for the dearth of stakeholders' pressure over companies ( $p$-value $<0.04$ at significance threshold of 0.05). Accordingly, the companies' size has significant effect on the respondents' realization to the stakeholders' pressure as a main barrier for Egyptian company to assure their CSR reports.

According to Panel C, Table V, there is significant effect for the respondents' experience over their recognition toward only two strands that may create an atmosphere for the diffusion of CSR assurance among Egyptian companies, suggesting the partial acceptance of $\mathrm{H}_{5}$. At the significance level of 0.01 , the results imply that the experience level affect the respondents view toward the prominent role of the unified CSR reporting guidelines ( $p$-value $=0.01)$ and the stakeholders' pressure $(p$-value $=0.00)$ in paving the road toward enhancing the spread of CSR assurance in Egypt. Panel $\mathrm{C}$, Table $\mathrm{V}$ reveals that the null hypothesis $\left(\mathrm{H}_{6}\right)$ that companies' size has no effect on the respondents' perceptions about the driving forces that encourage the diffusion of CSR assurance can be rejected. Accordingly, the observed significant level for all four items is lower than the 0.05 confidence level, implying that the companies' size influences the respondents' perceptions about each strand that pave the root to enhance the growing of CSR assurance in Egypt. 
Table V. Results for Kruskal Wallis Test

\begin{tabular}{|c|c|c|c|c|c|c|}
\hline \multirow[b]{2}{*}{ Items } & \multicolumn{3}{|c|}{ Level of Experience } & \multicolumn{3}{|c|}{ Companies' Size } \\
\hline & $\begin{array}{l}\text { Krus- } \\
\text { kal-Wallis H }\end{array}$ & Df & $\begin{array}{l}\text { Asymp. } \\
\text { Sig. }\end{array}$ & $\begin{array}{l}\text { Krus- } \\
\text { kal-Wallis H }\end{array}$ & Df & $\begin{array}{l}\text { Asymp. } \\
\text { Sig. }\end{array}$ \\
\hline \multicolumn{7}{|c|}{ Panel A: Incentives toward CSR assurance. } \\
\hline Improves its image for investors & 0.822 & 2 & 0.66 & 9.611 & 3 & $0.02^{* *}$ \\
\hline Improves employee's recruitment process & 0.344 & 2 & 0.84 & 11.908 & 3 & $0.01^{* * *}$ \\
\hline Improves customer appeal & 0.866 & 2 & 0.64 & 6.631 & 3 & $0.09 *$ \\
\hline Improves the company image among its stakeholders & 0.344 & 2 & 0.84 & 11.908 & 3 & $0.01 * * *$ \\
\hline Enhance credibility of CSR report & 2.033 & 2 & 0.36 & 9.611 & 3 & $0.02 * *$ \\
\hline Improves internal reporting process & 0.866 & 2 & 0.64 & 9.221 & 3 & $0.03^{* *}$ \\
\hline Improves external reporting & 2.13 & 2 & 0.34 & 0.248 & 3 & 0.97 \\
\hline Improves internal control process & 2.4 & 2 & 0.30 & 6.631 & 3 & $0.09 *$ \\
\hline \multicolumn{7}{|c|}{ Panel B: Challenges hinders the adoption of CSR assurance } \\
\hline Assurance fees are too high & 1.861 & 2 & 0.39 & 3.792 & 3 & 0.29 \\
\hline There is no pressure from stakeholders & 6.521 & 2 & $0.03^{* *}$ & 8.286 & 3 & $0.04^{* *}$ \\
\hline Third party assurance does not add any value to the report & 1.023 & 2 & 0.60 & 4.565 & 3 & 0.21 \\
\hline Credibility can be increased through other factors & 2.531 & 2 & 0.28 & 6.143 & 3 & 0.11 \\
\hline Lack of independence of CSR assurance providers & 8.696 & 2 & $0.01^{* * *}$ & 4.469 & 3 & 0.22 \\
\hline There is no awareness about the importance of the assurance & 4.55 & 2 & $0.10^{*}$ & 5.85 & 3 & 0.12 \\
\hline \multicolumn{7}{|c|}{$\begin{array}{c}\text { Panel C: Strands encourage the diffusion of CSR assurance } \\
\end{array}$} \\
\hline Providing generally accepted reporting guidelines & 7.47 & 2 & $0.01^{* * *}$ & 9.533 & 3 & $0.02^{* *}$ \\
\hline Increased pressure from stakeholders & 10.518 & 2 & $0.00^{* * *}$ & 7.854 & 3 & $0.05^{* *}$ \\
\hline $\begin{array}{l}\text { Increased awareness about the importance of third-party assurance } \\
\text { for CSR repots }\end{array}$ & 2.264 & 2 & 0.32 & 8.286 & 3 & $0.04^{* *}$ \\
\hline Proactive approaches from leading companies in the sector & 1.023 & 2 & 0.60 & 14.625 & 3 & $0.02 * *$ \\
\hline$*^{* * *} \mathrm{p}<.01,{ }^{* *} \mathrm{p}<.05,{ }^{*} \mathrm{p}<.1$ & & & & & & \\
\hline
\end{tabular}

\section{Additional Analysis}

Additional content analysis was conducted for the CSR reports of the companies chosen in the sample. In this section, we will highlight the main descriptive observations to capture the elements that were not included in the questionnaire. The objective of the additional analysis is to support our investigation for the current state of CSR assurance practices in Egypt. In terms of the way in which CSR information were reported, we found a variation in the reporting style among the companies. Some companies (almost 28 companies) reported their CSR activities only on their website pages with varied details disclosed. Some of the other companies (12 Companies) incorporated information about CSR activities in their annual reports. Around 17 companies prepared stand-alone reports. The language used was mostly English. The stand-alone reports were mainly found in Banks and environment-sensitive industries such as Cement and fertilizers manufacturing industries. Producing stand-alone CSR reports did not correlate with the years of experience in reporting for CSR. In many situations, companies issued their first sustainability report in a stand-alone format that covers more than one year of CSR activities.

In the standalone reports, companies were able to disclose detailed information about the social responsibility activities they conduct. On the other side, disclosing such information on websites or in the annual report does not provide the reader with similar level of details. With experiencing in reporting about CSR, organizations tend to give more details compared to earlier years of reporting. For example, the Sustainability Report for CIB in 2019 is almost double, in terms of number of pages, the report in 2018.

Some companies issue their CSR report based on GRI standards. The content of the report covers areas such as value creation, customers, economy, community, environment, and employees. Despite the 
differences in the content titles, they all can be classified in the three main pillars of CSR, economic, social, and environmental pillars. Other companies disclosed their social responsibility activities according to the United Nations Global Compact and its principles on human rights, labour, environment, and anti-corruption. On the other hand, companies that disclose their CSR activities in the annual reports do not follow any standards or principles in reporting about the sustainability activities.

The number of companies that have third party assurance for their reports and registered in EGX are six companies. Two of them are banks, three companies can be considered as environment-sensitive industry as they work in fertilizer and drilling industries and the final company is food production company. These companies were considered among the oldest companies in terms of their registration in EGX. As their years of registration ranges from 11 to 27 years. However, it was noticed that not all the companies have the longest experience in disclosing about their CSR activities. Surprisingly, three out of the six companies issued their first CSR report just in 2018. However, some of these reports covered CSR activities for years earlier than 2018. Some of them are quite experienced in reporting CSR activities (3 to 7 years of experience). All these companies have a stand-alone report. It was noted that companies that assure their CSR reports are companies that use GRI Standards in preparing their repots. Only one company that has an assurance statement and disclosed its CSR information based on the UN Global Compact Goals. However, the assurance provider for this company is an international consultancy firm.

\section{Conclusion}

The aim of this paper is to provide preliminary insights on the current corporate social responsibility reporting and assurance practices in Egypt. This section will discuss on the issues that emerged from the study and will provide recommendation for future in-depth studies to be conducted within Egyptian firms.

Based on the findings, social responsibility and assurance practices are observed as progressing in the Egyptian context. In most cases reporting were only on the website of the organization or included in their mandatory annual report. Few companies prepare stand-alone reports. However, there is a tendency of increasing the number of companies that prepare stand-alone CSR reports. This increase is observed because a considerable number of the companies that prepare stand-alone reports got involved in this practice lately in 2018 and later. This indicates that there is an increasing awareness of companies to publish their social responsibility activities separately and in a detailed format. Majority of companies that prepared CSR reports followed GRI standards in disclosing the information about social responsibility activities (cf. Sawani et al., 2010). Few companies followed the UN Global Compact Principles in reporting their activities. Despite the low level of assurance practices on CSR activities due to the low level of awareness, most respondents confirmed that assurance practices enhance the credibility of reports as well as improving the image of the company in front of its various stakeholders.

The study main objective was to explore the Egyptian context in terms of the social responsibility and assurance practices; however, the paper has some limitations. First, the research techniques used in this study were meant to be exploratory. So, only descriptive data were reported, no causal or relationship study was undertaken at this stage. Second, the small sample size makes the results of the study not reflective for the actual practices in Egypt; however, it contributes to future research in this area.

Our results have several practical implications. First, our results capture a recent picture of the hesitation status of Egyptian companies toward the assurance decision. Accordingly, the relatively modest spread of the CSR assurance practice among Egyptian companies may direct the attention of the standard setters toward the importance of refining the current reporting regulations to maintain a more transparent atmosphere for integrated reporting and assurance in Egypt. Second, one of the biggest issues that hinder the 
diffusion of CSR assurance among the Egyptian listed companies is the high cost of such service. Thus, the auditing firms should find avenues to provide the assurance service in much lower fees to in order to expand the package of service they provide. In this regard, the mass production strategy would compensate the forgone fees.

As noted in the findings of this research, contrary to findings from previous literature, the assurance providers in Egypt are mainly consultancy companies rather than auditing firms. Studying the reasons behind this phenomenon is out of the scope of this paper. So, future research could explore the reason behind the dominance of consulting companies on the field of CSR reporting assurance. As an exploratory study, the paper utilized questionnaire as a main tool for collecting data. Although this tool gives the opportunity to collect the perception of many respondents, it does not give an in-dept understanding of the participants perception about the activities of social responsibility inside organizations, the reporting process, and the assurance. Consequently, future research can use case study methodology to get an in-depth detail about the process of assuring CSR reports from both the assured and assurer parties. Finally, this study focused on companies registered in the Egyptian Stock Exchange. However, the researchers noticed that there is an increasing number of companies that assure their CSR reports and are not registered in the EGX. Future studies can focus on companies that assure their CSR reports regardless of their registration in EGX. 


\section{References:}

AA1000AS v3 (AA1000 Assurance Standard). (2020). Available at: aa1000as_v3_final.pdf (accountability.org) (accessed 03 September 2021).

- $\quad$ Ackers, B. (2008). "The need for corporate social responsibility assurance", In International Conference on Environment, pp. 1-18.

- Ackers, B. (2009). “Corporate social responsibility assurance: How do South African publicly listed companies compare?", Meditari: Research Journal of the School of Accounting Sciences, Vol. 1, No. 2, pp.1-17. https://hdl.handle.net/10520/EJC72576

- $\quad$ Ackers, B. (2017). "Independent corporate social responsibility assurance: a response to soft laws, or influenced by company size and industry sector?". International Journal of Disclosure and Governance, Vol. 14, No. 4, pp. 278-298 https://doi.org/10.1057/s41310-017-0026-7

- $\quad$ Ackers, B. and Eccles, N. S. (2015). "Mandatory corporate social responsibility assurance practices", Accounting, Auditing \& Accountability Journal, Vol. 28, No. 4, pp. 515 - 550 http://dx.doi. org/10.1108/AAAJ-12-2013-1554

- Al-Shaer, H. and Zaman, M. (2019). "CEO compensation and sustainability reporting assurance: Evidence from the UK", Journal of Business Ethics, Vol. 158, No. 1, pp. 233-252. https://doi. org/10.1007/s10551-017-3735-8

- Branco, M. C.; Delgado, C.; Ferreira Gomes, S. and Cristina Pereira Eugénio, T. (2014). “Factors influencing the assurance of sustainability reports in the context of the economic crisis in Portugal", Managerial Auditing Journal, Vol. 29, No. 3, pp. 237-252. https://doi.org/10.1108/MAJ-072013-0905

- Carrington, T. (2019). "A critical perspective on sustainability assurance", Arvidsson, S. (Ed.), Challenges in Managing Sustainable Business: Reporting, Taxation, Ethics \& Governance, Palgrave Macmillan, Cham, Switzerland, pp. 155-176.

- Channuntapipat, C.; Samsonova-Taddei, A. \& Turley, S. (2019). “Exploring diversity in sustainability assurance practice: Evidence from assurance providers in the UK", Accounting, Auditing \& Accountability Journal, Vol. 32, No. 2, pp. 556- 580. https://doi.org/10.1108/AAAJ-05-2017-2940

- $\quad$ Cho, C. H.; Michelon, G. M.; Patten, D. and W. Roberts, R. (2014). “CSR report assurance in the USA: an empirical investigation of determinants and effects". Sustainability Accounting, Management and Policy Journal, Vol. 5, No. 2, pp. 130-148. https://doi.org/10.1108/SAMPJ-01-2014-0003

- Darrag, M. and Crowther, D. (2017). "Reflections on CSR: The case of Egypt", Society and Business Review, Vol. 12, No.1, pp. 94-116. https://doi.org/10.1108/SBR-01-2016-0010

- Diab, A. A. and Abd-Elazim, S. I. (2018). “Assurance of integrated reports: An exploratory study from Egypt", Financial and Commercial Studies Journal, Vol. 28, No. 2, pp. 40-68.

- Dutta, P. (2020). “Determinants of voluntary sustainability assurance: the importance of corporate environmental performance", Social Responsibility Journal, Vol. 16, No. 8, pp. 14031414. https://doi.org/10.1108/SRJ-06-2019-0213

- $\quad$ Ernst and Young. (2010). “Climate change and sustainability: Seven questions CEOs and boards should ask 'about triple bottom line' reporting". Available at: 1009-1191617_CCaSS_SustainRep_ FQ0015.pdf (globalsustain.org)

- $\quad$ Fernandez-Feijoo, B.; Romero, S. and Ruiz Blanco, S. (2019). "Regional differences in industry specialization in the sustainability assurance market", Management Decision, Vol. 57, No. 3, pp. 669-687. https://doi.org/10.1108/MD-06-2017-0598 
Ghareb, H. A. S. (2015). “The Egyptian indicator for companies' responsibility about sustainable development: A new challenge for accountants and auditors in the light of governance principles", The Accounting Thought, Vol. 19, Issue 4, pp. 109-149, Ein Shams University, Egypt

- Gillet, C. (2012), "A study of sustainability verification practices: The French case", Journal of Accounting \& Organizational Change, Vol. 8, No. 1, pp. 62-84.https://doi. org/10.1108/18325911211205748

- Global Reporting Initiative. (2016). “GRI 101: Foundation”, Available at GRI - GRI Standards English Language (globalreporting.org) (accessed 03 September 2021)

- Herda, D. N.; Taylor, M. E. and Winterbotham, G. (2014). "The effect of country-level investor protection on the voluntary assurance of sustainability reports", Journal of International Financial Management \& Accounting, Vol. 25, No. 2, pp. 209-236.

- IFAC. (2013). "ISAE 3000 (revised), Assurance engagements other than audits or reviews of historical financial information", Available at ISAE 3000 Revised - for IAASB.pdf (ifac.org) (accessed 3 Sept. 2021).

- Jones, P.; Comfort, D. and Hillier, D. (2015). "Materiality and external assurance in corporate sustainability reporting: An exploratory study of UK house builders", Property Management, Vol. 33 No. 5, pp. 430-450. https://doi.org/10.1108/PM-03-2015-0014

- Kolk, A. and Perego, P. (2010). “Determinants of the adoption of sustainability assurance statements: an international investigation", Business Strategy and the Environment, Vol. 19, No. 3, pp.182-198 https://doi.org/10.1002/bse.643

- Mnif Sellami, Y.; Dammak Ben Hlima, N. and Jarboui, A. (2019). "An empirical investigation of determinants of sustainability report assurance in France", Journal of Financial Reporting and Accounting, Vol. 17, No. 2, pp. 320-342. https://doi.org/10.1108/JFRA-02-2018-0019

- Park, J. and Brorson, T. (2005). "Experiences of and views on third-party assurance of corporate environmental and sustainability reports", Journal of Cleaner Production, Vol. 13, No. 10-11, pp. 1095-106. https://doi.org/10.1016/j.jclepro.2004.12.006

- Ruiz-Barbadillo, E. and Martínez-Ferrero, J. (2020). "Empirical analysis of the effect of the joint provision of audit and sustainability assurance services on assurance quality", Journal of Cleaner Production, Vol. 266, pp.1-23. https://doi.org/10.1016/j.jclepro.2020.121943

- Sawani, Y.; Mohamed Zain, M. and Darus, F. (2010). “Preliminary insights on sustainability reporting and assurance practices in Malaysia", Social Responsibility Journal, Vol. 6, No. 4, pp. 627-645. https:// doi.org/10.1108/17471111011083482

- Sherif, D. H. (2016). "Expanding horizons in development: The rising role of the private sector", Available at Expanding Horizons in Development: The Rising Role of the Private Sector | UNDP in Egypt (Accessed 06 September 2021)

- Sierra, L.; Zorio, A. and García-Benau, M. A. (2013). "Sustainable development and assurance of corporate social responsibility reports published by Ibex-35 companies", Corporate Social Responsibility and Environmental Management, Vol. 20, No. 6, pp.359-370 https://doi. org/10.1002/csr.1303

Simnett, R.; Vanstraelen, A. and Chua, W. F. (2009). "Assurance on sustainability reports: An international comparison", The Accounting Review, Vol. 84, No. 3, pp.937-967. 